\title{
Oppimisen haasteet sukupuolinäkökulmasta
}

\author{
- Esimerkkinä tekstiili- ja vaatetusteollisuus
}

Tuula Heiskanen

\begin{abstract}
Sukupuolistuneiden käytäntöjen näkökulma soveltuu myös työssä oppimisen tarkasteluun. Ymmärrän työssä oppimisen, eli taitojen ja ongelmanratkaisuvalmiuksien kehittymisen ja työssä eteentulevien asioiden merkitysyhteyksien rakentamisen tapahtuvan valtaosaltaan niissä arkisissa käytännöissä, joihin työtätekevät osallistuvat. Organisaation käytännöt, mukaan lukien ne käytännöt, jotka rakentavat sukupuolta työpaikoilla, toimivat oppimisen ehtoina ja aikaansaajina.
\end{abstract}

\begin{abstract}
Atikkelini käsittelee osaamista, sen ylläpitoa ja kehittämistä työelämässä sukupuolinäkökulmasta. Empiirisen tutkimuksen kohteena oli tekstiili- ja vaatetusteollisuus, joka on läpikäynyt 1990-luvulla kriisinomaisia vuosia ja kohdannut aivan uudenlaisia oppimisen haasteita. Sukupuolinäkökulma osaamisen ja oppimisen kysymyksiin ei asetu mitenkään keskustelun ja tutkimuksen valtavirtaan sen paremmin oppimistutkimuksessa kuin sukupuolitutkimuksessakaan. Sen vuoksi on tarpeen taustoittaa näkökulman muotoilua.
\end{abstract}

Koska itse työskentelen työelämän tutkijana, näkökulmani on muotoutunut sellaisessa tutkimusja keskustelukentässä, joka ottaa sukupuolinäkökulman työelämän ilmiöihin. Sukupuolta on käsitelty ja käsitellään suomalaisessa työelämän tutkimuksessa monin eri tavoin ja tutkimusottein. Seuraavassa käsiteltävät tutkimustyypit ovat eläneet rinnakkain, vaikka toki painopisteen siirtymiä on ollut havaittavissa (Heiskanen ym. 1990, Kinnunen \& Korvajärvi 1996).
Yksi tutkimussuuntaus asettaa ihmisen edustajaksi miehen. Tällöin työelämän tutkimuksen kohteena on vain miehiä, mutta tulosten on katsottu edustavan molempia sukupuolia. Toinen tutkimussuuntaus ottaa kohteeksi sekä miehiä että naisia, mutta sivuuttaa sukupuolen käsitteellisesti. Sukupuolta käsitellään yhtenä taustamuuttujana, mutta sukupuoli katoaa siinä vaiheessa, kun siirrytään empiirisestä käsitteelliseen ja teoreettiseen analyysiin.

$\mathrm{T}$ asa-arvoideologian ja naisliikkeen nousun myötä 1960-luvun lopulla alettiin tehdä tutkimuksia tasa-arvolähtökohdista. Tasa-arvokäsitteen sisältö on muuttunut merkitykseltään ajan myötä, mutta yleensä käsitteen taustalla on ollut käsitys naisten ja miesten samanlaisuudesta (Korvajärvi \& Lehto 2000, Holli 1995). Niinpä työelämän tutkimus on tarkastellut, miten tämä samanlaisuuden idea toteutuu työelämässä vertailemalla naisten ja miesten asemia ja mahdollisuuksia toisiinsa. Tasa-arvolähtökohdista tehdyllä tutkimuksella on ollut yleensä selvä käytäntö- ja 
politiikkasidos. Havaitut erot naisten ja miesten välillä on nostettu esille epätasa-arvo-ongelmina, joihin ratkaisuksi on esitetty yhtäläisten mahdollisuuksien tarjoamista naisille ja miehille.

Naisliikkeen ja naistutkimuksen muotoilema kysymyksenasettelu naiserityisyydestä (Hartsock 1983) on synnyttänyt tutkimusta myös työelämän alueella. Tutkimus lähtee ajatuksesta, että naisilla on omia kokemuksia ja taitoja, joita he käyttävät työelämässä. Olennaista lähestymistavassa on ollut naisten tutkiminen toimijana työelämässä, naisille tyypillisten toimintatapojen tutkiminen sekä naisten toimintatapojen kytkeminen siihen rakenteelliseen asemaan, jossa naiset ovat työelämässä. Tutkimus on nostanut erityisesti esille naisten ääntä ja työ- ja toimenkuvien ulkopuolelle jääviä piiloisia taitoja naisten työssä.

Tasa-arvolähtökohta ja naiserityisyyden lähtökohta käsittelevät kumpikin naisia ja miehiä ryhminä, kuten Korvajärvi ja Lehto (2000) huomauttavat. Heidän mukaansa tasa-arvolähtökohdista tehdyssä tutkimuksessa liikutaan organisaatioiden virallisella areenalla kun taas naiserityisyystutkimuksessa liikutaan epävirallisella areenalla. Tasa-arvoperspektiivistä tehdyssä tutkimuksessa sukupuoli näkyy numeroina, jakoina, päätöksinä ja vaatimuksina. Naiserityisyyden näkökulma tekee näkyväksi, millä tavoin sukupuoli sisältyy vakiintuneisiin olettamuksiin, organisaatiokulttuuriin ja työorientaatioihin.

Sukupuolen ymmärtäminen suhteena, joka rakenteistaa kaikkia yhteiskunnallisia ilmiöitä, siirtää painopisteen miehistä ja naisista ryhminä sukupuolistuneisiin rakenteisiin ja käytäntöihin yhteiskuntaelämän eri alueilla. Lähestymistavasta seuraa tutkimukselle väistämättä vaatimus ottaa huomioon toisiinsa sidoksissa olevia tasoja ihmisten toiminnasta ja merkityksenannoista. Sukupuoli on läsnä rakenteissa, kulttuurisissa merkityksissä, sosiaalisessa vuorovaikutuksessa, identiteeteissä, ruumiissa ja haluissa. Niinpä tutkimuksen pitäisi kyetä jäljittämään sukupuolen rakentumista eri tasoilta; rakenteista, sosiaalisesta vuorovaikutuksesta, symboleista ja ajatuksista (Acker 1992). Sukupuolistuneiden käytäntöjen näkökulma, jota tässä artikkelissa sovelletaan rat-

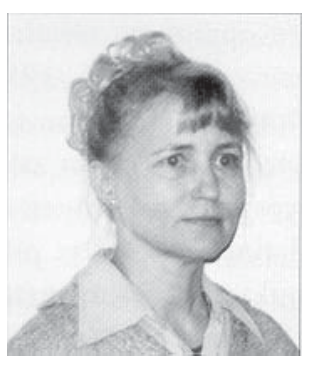

Tuula Heiskanen

kaisee eri tasoilla liikkumiseen liittyvän metodologisen ongelman suuntaamalla huomion tavallisiin arkisiin toimintoihin ja asioihin, joita ihmiset suorittavat ja käsittelevät. Systeemi- ja prosessikäsitteistä poiketen käytäntönäkökulma suuntaa huomion väistämättä konkreettisiin sosiaalisiin toimijoihin. Käytäntö on sitä, mitä ihmisen tekevät, uudelleen ja uudelleen. Kohdistettaessa huomio käytäntöön voidaan kysyä, kuka tekee, miten, missä, koska, missä olosuhteissa (Rantalaiho ym. 1997).

Sukupuolistuneiden käytäntöjen näkökulma soveltuu myös työssä oppimisen tarkasteluun. Ymmärrän työssä oppimisen, eli taitojen ja ongelmanratkaisuvalmiuksien kehittymisen ja työssä eteentulevien asioiden merkitysyhteyksien rakentamisen tapahtuvan valtaosaltaan niissä arkisissa käytännöissä, joihin työtätekevät osallistuvat, vaikka toki järjestetyllä opetuksellakin on jokin sijansa työssä oppimisessa. Organisaation käytännöt, mukaan lukien ne käytännöt, jotka rakentavat sukupuolta työpaikoilla, toimivat oppimisen ehtoina ja aikaansaajina.

Tutkimuksen kohteena ollut tekstiili- ja vaatetusteollisuus on kokenut 1990-luvulla suuria ja nopeita muutoksia liiketoimintaympäristössään. Artikkeli käsittelee uuteen liiketoimintaympäristöön sopeutumisesta seuraavia oppimishaasteita sukupuolinäkökulmasta.

\section{Kriisiytynyt teollisuudenala}

Liiketoimintaympäristön nopeat muutokset ovat pakottaneet eurooppalaisen tekstiili- ja vaatetusteollisuuden etsimään uudenlaisia liiketoimin- 
takonsepteja ja tuote- ja markkinointistrategioita. Työvoimavaltaiselle teollisuudenalalle erityisesti matalapalkkamaista tapahtuva tuonti on ollut kohtalokasta. Rakenteelliset muutokset tilanteeseen sopeutumiseksi alkoivat monissa läntisen Euroopan maissa aikaisemmin kuin Suomessa, mutta kun Suomen vuoro tuli, muutos on ollut erityisen jyrkkä.

Kahdenkeskinen kauppa entisen Neuvostoliiton kanssa oli elintärkeä Suomen tekstiili- ja vaatetusteollisuudelle. Kun kaupankäynti kuihtui ja samaan ajankohtaan osui koko talouden pitkä ja vaikea lama, teollisuudenala ajautui kriisiin. Edessä oli ohdakkeinen tie löytää uusia markkinoita läntisistä maista ja sopeuttaa tuotanto laajempaan tuotevalikoimaan ja lyhyempiin toimitusaikoihin. Parannuskeinoina on käytetty joustavan tuotannon periaatteiden soveltamista ja tuotannon valmistavien vaiheiden siirtämistä muualle, erityisesti Baltian maihin.

Tuotanto on muuttunut entistä asiakassuuntautuneemmaksi. Yritykset pyrkivät vastaamaan asiakkaiden toiveisiin niin malleissa, laadussa kuin toimitusajoissakin. Perusvaatimus tällaisessa tilanteessa on, että tuotantoketjun pitää olla erittäin hyvin koordinoitu, jotta asiakkaan vaatimukset voidaan täyttää. Kun osa tuotannosta tapahtuu Suomessa ja osa ulkomailla, koordinointi ja tuotantoaikataulujen sovittelu ovat aikaansaaneet uudenlaisia ongelmia. Yhä enenevässä määrin tuotannon organisoinnissa on otettu käyttöön ryhmätyö, mikä lisää yhteistyön ja vuorovaikutuksen tarvetta. Tämä tilanne on synnyttänyt merkittäviä kommunikatiivisen oppimisen haasteita monilla eri tasoilla.

\section{Oppimine n}

Erilaiset oppimisteoreettiset näkökulmat ovat antaneet aineksia yritykselleni tunnistaa yksilöllisiä ja yhteisöllisiä oppimishaasteita kriisin keskellä elävissä työorganisaatioissa. Laven , Wenger'n ja Snyder'n (Lave 1993, 1996, Wenger \& Snyder 2000) lähestymistapa tutkia oppimista käytännön yhteisöissä tapahtuvana sosialisaationa on lähisieluinen työelämän sukupuolistuneita käytäntöjä tutkineelle tutkijalle. Kom- munikatiivisen oppimisen termin olen ottanut käyttöön Mezirov'lta (1985, 1995). Päivittäisissä työkäytännöissä joudutaan toistuvasti vastaamaan kysymykseen "miten asiat pitäisi tehdä" mutta myös "miten ihmisten välisessä kanssakäymisessä ilmenevät asiat pitäisi tulkita”. Mezirov'n mukaan ensimmäinen kysymys on välineellisen oppimisen haaste ja jälkimmäinen kysymys kommunikatiivisen oppimisen haaste. Kommunikatiivinen oppiminen viittaa hänen mukaansa tilanteisiin, joissa ihmiset ollessaan tekemisissä toistensa kanssa tekevät tulkintaa, mitä toiset puheellaan tarkoittavat ja mihin väitteensä perustavat. Avainasia kommunikatiivisessa oppimisessa on sellaisten viitekehysten etsiminen, joissa sosiaalisessa vuorovaikutuksessa ilmenevät asiat tulevat ymmärrettäviksi. Käytän termiä yhteydessä, jossa on tarve, Weick'n (1995) ilmausta käyttäen, organisaatiotasoiseen merkityksenantoon, eli asioiden laittamiseen jonkinlaiseen kehykseen. Käytän kommunikatiivisen oppimisen käsitettä Argyris'n ja Schön'n määrittelemän organisaatiotasoisen oppimisen mallin sisällä. Organisaatiotasoisen oppimisen käsite avaa näköalan niihin normeihin, strategioihin ja olettamuksiin, jotka ohjaavat päivittäisiä käytäntöjä samoin kuin tilanteisiin, joissa uudet vaatimukset kyseenalaistavat vanhat käytännöt ja niiden takana olevat olettamukset. Kiinnitän oppimisen kohteeksi valitun teollisuudenalan johtamisstrategioiden ja liiketoiminnan reunaehtojen yhteyteen.

\section{Toimintatutkimusprojekti}

Artikkelin pohjana oleva empiirinen materiaali on peräisin tekstiili- ja vaatetusteollisuutta koskevasta tutkimuksesta (Heiskanen ym. 1995, Heiskanen ym. 1998). Kysymyksessä oli toimintatutkimuksellinen hanke, jossa tutkijat olivat mukana useamman vuoden ajan tutkimassa yritystasoisia muutoksia ja tukemassa yrityksiä, kun nämä etsivät strategioita paremmalle tulevaisuudelle. Tutkimus liittyi sosiaalisten innovaatioiden tuottamiseen kahdessa mielessä. Ensinnäkin se pyrki ymmärtämään teollisuudenalan kehitystrendejä kytkien yrityskohtaiset ehdot ja edellytykset liiketoiminnan globaaleihin ehtoihin. Tarkastelun keskiöön otettiin yritystasoiset käy- 
tännöt, joilla yritykset pyrkivät vastaamaan pyörteisen liiketoimintaympäristön vaatimuksiin. Käytäntöjä peilattiin yritysten sosiaaliseen ja kulttuuriseen maailmaan. Tutkimusryhmän jäsenet, kirjoittajan lisäksi Riitta Lavikka, Leena Piispa ja Pirjo Tuuli ovat käsitelleet tieteellisissä kirjoituksissaan tuloksia muun muassa naistyön hyödyntämisen, ulkomaisen alihankinnan, yritysten yhteistyösuhteiden, työssä käytettyjen kontrollimuotojen, kuormittumisen, naisten työkulttuurin, oppimishaasteiden ja kehittämistyön ehtojen näkökulmasta (Heiskanen ym. 1995, Heiskanen ym. 1998, Lavikka 1997, Piispa ei vuosilukua, Tuuli 2001). Toiseksi tutkimus oli antamassa virikkeitä sellaisten käytäntöjen muodostamiselle, jotka ovat perusedellytyksiä jatkuvaa oppimista tukeville ympäristöille. Kenttätyö koostui tutkimusryhmän järjestämistä työkonferensseista seitsemälle tutkimukseen osallistuneelle yritykselle, yrityskohtaisista kehittämisseminaareista, observointijaksoista ja palautetapaamisista, joissa tutkijat kertoivat tuloksistaan ja tulkinnoistaan yritysten henkilökunnalle.

Tutkimusryhmän järjestämissä keskustelutilaisuuksissa kohtautettiin sekä eri yritysten että eri henkilöstöryhmien näkemyksiä. Näköaloja täydentävänä tapahtumana oli seminaari, jossa osanottajina oli tutkimuksen kohteena olleiden yritysten ja elinkeinotoiminnan tukijärjestelmän edustajia sekä työelämän tutkijoita. Näiden erityyppisten keskustelujen tavoitteena oli antaa mahdollisuus paitsi vaihtaa ajatuksia kokemuksista ja konkreettisista ratkaisuista ja uudistuksista, joita eri puolilla oli toteutettu, myös rakentaa ymmärryskehyksiä. Työpaikoilla tapahtuneet henkilö- ja ryhmähaastattelut toimivat paitsi tiedonhankinnan väylinä tutkijoille, myös tilaisuuksina, joissa haastateltavat saattoivat pysähtyä pohdiskelemaan omaa työtään ja yrityksen asioita tavalla, johon normaali työn arki ei tarjonnut kanavia.

Mukana olleet seitsemän yritystä / yksikköä olivat eri puolilta Suomea ja erikokoisia, henkilökunnan määrän vaihdellessa 30-270 välillä. Useimmissa yksiköissä sovellettiin ryhmätyöorganisaatiota, mutta myös perinteinen vaihetyömalli oli käytössä.

\section{Op pimishasteet}

Kiivas työtahti leimasi työtä ja työilmapiiriä monella tapaa tutkimuksen kohteena olleissa tehtaissa. Kiire ja ruuhkat olivat niissä yhtä lailla ongelmanratkaisun reunaehtoja kuin kyky mukautua lyhyelläkin varoitusajalla asiakkaan toiveisiin koskien tuotteiden malleja, laatua ja määrää. Yrityksissä oli täytynyt löytyä toimivat muodot päivittäisongelmien ratkaisuille. Tietysti muodot vaihtelivat sekä yrityksen koon, työnorganisoinnin ja työkulttuurin mukaan. Kun pienessä yrityksessä oli mahdollista toimia toimintamallilla, jossa tuotantopäällikkö oli ongelmanratkaisun avainhenkilö, isossa yrityksessä oli väistämättä sitoutettava useampia osapuolia.

Pienen Käyttövaatetehtaan valttikorttina oli pitkälle viety tuotannon asiakaslähtöisyys. Tuotannossa lomittuivat yrityksen oman malliston pitkät sarjat ja asiakkaiden toiveiden mukaiset, hyvinkin lyhyellä toimitusajalla luvatut pienet valmistuserät. Tilanteiden nopeat vaihtumiset, muutokset ja mukauttamiset olivatkin jokapäiväistä arkea.

Tuotantopäällikkö hoiti tilausten koordinoinnin ja työn järjestämisen. Tuotantopäällikön ja työntekijöiden yhteistyö oli tiivistä ja saumatonta ja rooliodotukset puolin ja toisin selkeät. Tuotantopäällikkö vastasi ongelmanratkaisusta, työntekijät mukautuivat tilanteisiin ja muutoksiin sen mukaisesti, kuin tuotantopäällikkö ne määritteli. Työntekijät, vaikkakin vaihetyöntekijöitä, olivat monitaitoisia ja kykenivät vastaamaan mukautumisvaatimuksiin. Tuotantopäällikön ongelmanratkaisijan rooli edellytti ja oli mahdollista vain sitä kautta, että hän oli koko ajan mukana tuotannossa.

Myös isommissa yrityksissä tuotanto/valmistuspäälliköllä oli tärkeä rooli tuotannollisten ongelmien ratkaisijana ja puskurina äkillisten tilanteiden edessä. Selvänä erona edelliseen esimerkkiin oli se, että niissä oli täytynyt rakentaa ennakoivia järjestelmiä, joiden kautta tilanteisiin voitiin orientoitua jo ennen kuin ne olivat muodostuneet ongelmiksi. Ryhmien yhdyshenkilöiden palaverit ovat hyvä esimerkki tällaisesta 
järjestelmästä. Yhdessä yrityksessä oli havaittu hyväksi käytännöksi se, että ryhmien koordinaatiotehtäviä ja "ulkosuhteita" hoitavat ryhmien yhdyshenkilöt kokoontuivat säännöllisin väliajoin yhdessä tuotannon johdon kanssa. Tavoitteeksi palavereille oli asetettu pohtia yhdessä tuotannossa ilmenneitä ongelmia sekä välittää tietoja ja ideoita puolin ja toisin. Toisessa yrityksessä tuotannonjohto järjesti pari kertaa vuodessa kierroksen, jonka tavoitteena oli kartoittaa jokaisen ryhmän kanssa erikseen niiden kokemat tuotannolliset ongelmat.

Toimihenkilö- ja esimiesportaassa oli omat palaverikäytäntönsä, jotka toimivat samoin ongelmia ennakoivina ja ratkovina järjestelminä. Joissakin tehtaissa oli vakiintunut tuotannonohjaus- ja laatupalaverikäytäntö osastojen vastuuhenkilöiden kesken, joissakin toisissa asiat hoidettiin epävirallisemmin muodoin.

Ryhmissä ongelmien käsittely tapahtui pitkälti ryhmän sisäisenä itsenäisenä toimintana. Ryhmä paikansi ongelman, huolehti tarvittavat yhteydenotot ulospäin ja määritteli sisäisen työnjaon ongelmatilanteen hoidossa. Autonomian alassa ja rajoissa oli kysymys paitsi ulkoisesta, myös sisäisestä määrittelystä. Ryhmien välillä oli ammattitaitoon ja ryhmädynamiikkaan liittyviä eroja itseohjautuvuudessa; jotkut ryhmät halusivat hoitaa ongelmat mahdollisimman pitkälle itse, jotkut turvautuivat helpommin esimiehen apuun. Ihmissuhdeongelmat olivat erityislaatuinen ongelmaryhmä. Niissäkin tilanteissa, joissa tuotannolliset ja työn järjestelyyn liittyvät ongelmat hoituivat ryhmän sisällä, ihmissuhdekonfliktien purkamiseen saatettiin tarvita esimiesporrasta.

Kun ryhmätyöorganisaatiossa ongelmien ennakointia tapahtui jo suunnitteluvaiheessa, vaihetyössä vastaavaa ennakoivaa ongelmanratkaisua tuotannon suunnittelun ja vaiheiden suorittajien välillä ei ollut. Palaute uuden mallin synnyttämistä ongelmista tuli vasta siinä vaiheessa, kun tuote oli jo valmistuksessa.

Ryhmätyössä tuotannon sujumiseen liittyvä päivittäisongelmien ratkaisu tuotti hyvin organi- saatiotasoista oppimista. Erityisesti tämä koskee ryhmän sisäistä oppimista ja ryhmän ja tuotannon suunnittelun välisiä yhteyksiä. Oppimisen siirtyminen ryhmien välillä oli sen sijaan alttiimpi tilannekohtaisille ehdoille, kuten ryhmien keskinäiselle kilpailutilanteelle, henkilösuhteille ja tiedottamiskäytännöille. Ryhmien yhdyshenkilöiden palaverit toimivat välittävänä rakenteena oppimisen siirrolle. Vaihetyössä rakenteelliset ehdot eivät vastaavassa määrin stimuloineet organisaatiotasoista oppimista. Ongelmien tunnistaminen, niistä neuvottelu ja ratkaisun hakeminen yhdessä esimiehen kanssa olivat olennaisesti yksilöllisen aloitteen varassa. Toki työntekijät kyselivät neuvoja toisiltaan ja antoivat palautetta jo siitäkin syystä, että työ sitoi perättäisten vaiheiden suorittajat toisiinsa. Kuitenkin vaihetyössä itsenäisten ratkaisujen ala oli kapea ja orientaatiota työhön määrittivät oman työpisteen tapahtumat. (Heiskanen 1998, 168-171) Osa päivittäisongelmista oli sellaisia, jotka olivat periaatteessa vähäisillä toimintatapojen muutoksilla korjattavissa, osa oli taas, oppimisterminologiaa käyttäen, kommunikatiivisen oppimisen haasteita. Seuraavassa valaisen muutamalla esimerkillä jälkimmäisiä haaasteita.

\section{Esimerkki 1.}

Ziire oli merkittävä reunaehto ongelmanrat kaisulle tutkimuksen kohteena olleissa tehtaissa. Mutta kuinka tämä reunaehto pitäisi ymmärtää? Eri ammattiryhmät ja osapuolet katselivat kiiretilanteita eri viitekehyksistä ja antoivat niille erilaisen merkityksen. Kiireessä osapuolilla ei välttämättä ole tarpeeksi informaatiota tilanteen käsittelemiseksi. Kiireen käsite on suhteellinen, kuten muun muassa seuraavasta sananvaihdosta ilmenee.

Valmistuspäällikkö: "Se tarkoitus on, että sarja tehdään valmiiksi. Että poikkeustapauksia kun tulee, jokin kiire, niin silloin keskeytetään, muttei muuten. Se on perussääntö se.” Ompelija: “ Mutta mitenkäs sitten - tuli tässä mieleeni että kun näitä listoja tulee, niin sieltä tulee 'kiire', 'heti', 'välittömästi'... Niin mikä näitten kiireellisyysjärjestys on?” Johtaja: “ Meidän täytyy selventää sanastoa: 'helvetin pian' - se on ykkönen." 


\section{Esimerkki 2.}

Tutkimusryhmä alusti keskustelun pystysuorasta eli vertikaalisesta yhteistyöstä. Kysymys koski sitä, voisivatko esimerkiksi jonkin tuoteryhmän suunnittelijat, myyjät, sarjojat, leikkaajat ja ompelijat muodostaa eräänlaisen vertikaalisen tiimin, jolle muodostuisi käsitys, mitä koko ketjuun kuuluu ja millaisista ammattitaidoista kyseisen tuotteen suunnittelu, valmistus ja myynti muodostuu. Johtaja: "Vertikaalinen ajattelutapa, se on hyvin hedelmällinen ja näinhän sen varmasti pitäisi olla. Mutta taas tullaan siihen rahaan. Jos rakennetaan semmoisia ryhmätöitä, jotka tekee työtä sillä tavoin, eikä siitä kumminkaan synny mitään valmista myytävää tulosta, niin kuinka kauan meillä on varaa maksaa tämmöisestä vertikaalisesta kommunikaatiosta?..." Tutkija: "Sen voisi nähdä toisinkinpäin, että sitä kautta se tuote kehittyisi ja sen tuotteen tekeminen kehittyisi siten, että sitä olisi parempi myydä ja se toisi paremmin leipää.” Toimitusjohtaja: "Voisiko tässä nyt tutkijalta kysyä, että oletatteko te todella, että emme me ole joutuneet tekstiiliteollisuudessa hakemaan sille tuotteelle ne kehitysraamit, mitä sille on ikinä tehtävissä tähän päivään mennessä?"

Keskusteluaihetta pohjustaessaan tutkimusryhmällä oli mielessään sekä hyviä esimerkkejä yhteistyöstä että eri henkilöstöryhmiltä tulleita ilmauksia yhteistyön kitkakohdista. Vertikaalisen yhteistyön puuttumisena tai katkoksina näyttäytyivät tilanteet, joissa tieto tai palaute ei kulkenut tai joissa ongelman hoidon kannalta olennainen asiantuntemus jätettiin huomiotta. Tällaisia esimerkkejä tuli esille sekä henkilöhaastatteluissa että eri henkilöstöryhmien edustajilta yhteisissä keskusteluissa.

\section{Esimerkki 3.}

Ryhmätyössä tarvitaan koordinaattoria. Koordinaattorin roolin määrittely synnytti ristiriitoja tehtaissa. Tehtävävaatimukset eivät tuntuneet sopivan perusluokkiin, joiden avulla tehtaiden toimintoja oli totuttu hahmottamaan. Tehtävävaatimuksissa oli samanaikaisesti sekä työnjohto-, toimihenkilö- että suorittavan työn piirteitä. Tehdassalissa esitetty kysymys, onko yhdys- henkilö työntekijöiden luottamushenkilö johdon suuntaan vai johdon edustaja, ryhmässä osoittaa tulkintojen liikkuma-alan. Tilanne synnytti määrittelyongelmia, jotka askarruttivat sekä yhdyshenkilöiksi valittuja että muita ryhmissä toimivia. Määrittely liittyi sekä yhdyshenkilön että ryhmän autonomiaan ja vastuisiin.

\section{Esimerkki 4.}

Liiketoiminnan reunaehdot ovat olleet tekstiili- ja vaatetusteollisuudessa kovat: hyväksyä kovat lääkkeet tai tuhoutua. Niissä olosuhteissa työllisyyden säilyttämisen viitekehys oli palkansaajien mielissä ehdottoman hallitseva eikä muunlaisille katsantokannoille jäänyt juurikaan tilaa. Työntekijät tekivät pitkiä työpäiviä, kun yrityksen tilauskirjat olivat täynnä, koska seuraavalla viikolla tai muutaman viikon sisällä tilanne saattoi olla jälleen toinen lomautuksineen ja irtisanomisineen. Siitä huolimatta, että työ sellaisissa oloissa tuotti voimakasta ruumiillista ja henkistä kuormitusta, kuormituksen kysymykset eivät nousseet asialistalle tehtaiden sisäisessä elämässä.

Työkonferenssissa tutkijaryhmä pyysi yrityksiä pohtimaan, mitkä ovat olleet ne keskeiset vahvuustekijät, joiden varassa ne ovat selvinneet taloudellisesti vaikeiden aikojen yli, ja mihin ne tukeutuvat tulevaisuuden perspektiiveissään. Kaikki yritykset korostivat ammattitaidon merkitystä. Siihen nähden, että ammattitaidon merkitys nousi niinkin vahvasti esille, yritysten suhdetta ammattitaitoa ylläpitäviin ja kehittäviin toimenpiteisiin voi luonnehtia pidättyväiseksi. Yrityksissä oli joitakin opetuksellisia järjestelyjä, jotka oli sovitettu päivittäiseen työhön ja myöskin sopimuksia koulutusinstituutioiden kanssa. Järjestetyn opetuksen rinnalla ja sijasta yrityksissä oli sanoiksi pukematon luottamus ammattitaidon siirtoon työssä oppimisen kautta. Erään johtotason henkilön lausuma näkemys muotoilee pelkistetysti reunaehdot ammattitaidon kehittämiselle: "Tämä on taloudellista toimintaa eikä opetusta. Se täytyy muistaa aina, että se on ensimmäinen lähtökohta. Mutta... se on tietysti sitä taloudellista toimintaa sekin, että jollakin tavalla tapahtuu se uuden oppiminen." (Heiskanen 1998, 171-175) 


\section{Tulosten tulkinta s u kupu o li näkökulmas ta}

\section{Kohti joustavuutta}

Tekstiili- ja vaatetusteollisuus on nojautunut niin Suomessa kuin muuallakin perinteisesti tayloristisiin periaatteisiin työn organisoinnissa. Nämä periaatteet ovat merkinneet hienojakoista työnjaollista erikoistumista ja tiukkaa eriytymistä hierarkkisiin asemiin. Selväpiirteinen jako toisaalta johto- ja työnjohtotehtäviin ja toisaalta lattiatason tehtäviin ovat olleet itsestäänselvä viitekehys vallanjaolle ja sosiaalisille suhteille tehtaiden arjessa. Tuotantoteknologian kehittyminen tällä teollisuudenalalla on ollut yhteensopiva tayloristisen työn organisoinnin kanssa (Banke \& Binder 1992, Winterton 1992).

Muutokset yritysten toimintaympäristössä ovat haastaneet tayloristisen organisoinnin perustan. Kilpailu laadussa, muodissa ja hinnoissa on lisääntynyt kaikkialla läntisessä Euroopassa ja asiakkaat ovat alkaneet vaatia yksilöllisiä vaatteita teollisilla hinnoilla. Hajanaisten tuotemarkkinoiden tilanne vaatii erilaista joustavuutta, kuin tayoristiset periaatteet voivat tarjota. Joustavan erikoistumisen (Piore \& Sabe 1984) ja joustavan organisaation (Atkinson 1984) mallit ovat tarjonneet lupaavampia tulevaisuuden perspektiivejä.

Leena Piispa (1998, 93-94) on analysoinut sukupuolistuneen tehdashallinnon käsitteen (vrt. Burawoy 1985, factory regime; Acker 1994, gender regime) avulla työvoiman käyttöä tutkimuksen kohteena olleissa tehtaissa. Joustavan tehdashallinnon ideaali nojaa epävarmuuden ja äkillisten tuotantohäiriöiden monitaitoiseen työtehtävien hallintaan. Työn organisoinnin tavoitteena on sujuva työn kulku, jossa työtehtävien suunnittelu on osittain palautettu työntekijöille, osittain kytketty tietojärjestelmiin. Työntekijöiden odotetaan ratkaisevan laatuvaatimuksia ja aikatauluja koskevat ongelmat itsenäisesti. Työnjaollisesti joustava organisaatio on vähemmän eriytynyt kuin tayloristinen organisaatio.

Leena Piispa havaitsi, että joustavan tehdashal- linnon ideaali eli tehtaissa rinta rinnan tayloristisen organisaation periaatteiden kanssa. Käytännöllisenä menettelynä joustavan tehdashallinnon juurruttamisessa oli ennen kaikkea ryhmätyön käyttöönotto entistä suuremmassa määrin. Tutkituissa tehtaissa aikaisempi vaihetyö oli organisoitu osittain tai kokonaan ryhmätyöksi. Keskustelut johtajien ja työntekijöiden kanssa paljastivat, että joustavuutta otettiin käytäntöön taylorististen normien alaisuudessa. Kaikissa tapauksissa ryhmätyö hajautti joissakin suhteissa vastuuta ja päätöksentekoa ja toivottuna tuloksena helpotti tuotantohäiriöiden hoitoa ryhmissä. Potentiaalinen perspektiivi ammattitaitojen laajentamiseksi ei sen sijaan ollut yhtä yksiselitteinen tulos, vaan riippui paikallisista ratkaisuista ryhmien organisoinnissa. Ristiriitojen alue vanhojen ja uusien normien välillä oli kaikkein selkeimmin näkyvissä palkkausjärjestelmissä. Palkkausjärjestelmät ottivat huomioon sekä yksilölliset taidot että ryhmien suoritustason, mutta eivät ottaneet selvää kantaa ammattitaitojen kehittymiseen ja kehittymisestä palkitsemiseen.

Leena Piispa on käyttänyt sukupuolistuneen tehdashallinnon käsitettä viittamaan sekä eksplisiittisiin että implisiittisiin puoliin organisaation käytännöissä (vrt Rantalaiho \& Heiskanen 1997). Sekä tekstiili- että vaatetusteollisuus ovat olleet ja ovat edelleen naisvaltaisia aloja Suomessa. Näiden alojen teollisuus on alueellisesti keskittynyttä ja sijaintipaikkakunnillaan ne ovat merkittäviä naispuolisen työvoiman työllistäjiä. Huomattava enemmistö työntekijöistä on naisia ja työnjako on segregoitunut sukupuolen mukaan. Nais- ja työvoimavaltaisena alana tekstiili- ja vaatetusteollisuus kuuluu yhteiskunnan matalapalkka-aloihin. Nämä tosiasiat antavat eksplisiittisesti sukupuolistuneen viitekehyksen johtamisstrategioille, vaikka johtamisstrategioista puhutaan useimmiten sukupuolineutraalein termein. Sukupuolen huomioonottaminen sisältyy johtamisstrategioihin myös implisiittisemmin naisten joustavuuden hyväksikäytön kautta.

\section{Joustavat naiset}

Työvoiman naisvaltainen kokoonpano oli näkyvillä tutkittujen tehtaiden sosiaalisessa maailmas- 
sa. Naistyöntekijät olivat kehittäneet tietynlaisen työkulttuurin, joka auttoi heitä kohtaamaan joustavuuden vaatimukset. Riitta Lavikka (1997) on kuvannut tämän työkulttuurin piirteitä ja toimintaa emotionaalisen rationaliteetin käsitteellä. Hänen mukaansa tämän kulttuurin kantavat ideat ovat yhteisöön suuntautuminen, jakaminen, keskinäinen tukeminen, huolenpito ihmisistä ja vastuu kokonaisuudesta ( s. 271). Työkulttuuri on tarjonnut vastakulttuurin tayloristiselle hierarkkisen johtajuuden ja yksilöllisistä palkinnoista kilpailemisen perinnölle. Naisten kulttuurinen tila auttoi heitä kehittämään selviämisstrategioita ristiriitaisten normien kohtaamiseen ja luomaan merkityksellisyyden kokemuksia työlleen. Vaikka suunnittelun, yhteistyön ja kasvaneen vastuun uudet ulottuvuudet naisten työssä eivät tulleet asianmukaisesti palkituiksi, he kykenivät ylittämään emotionaalisesti tämän symbolisen näkymättömyyden ja tuntemaan autenttista merkityksellisyyttä työssään omassa kulttuurisessa tilassaan.

Lavikka (s. 213) esittää, että uuden taloudellisen rationaliteetin mallin ja tuotteita valmistavissa naisryhmissä ilmenevän emotionaalisen rationaliteetin mallin välillä näyttää olevan tietynlainen rakenteellinen yhteensopivuus, homologia. Kehittymässä oleva taloudellisen rationaliteetin refleksiivinen muoto tarvitsee joustavia ja autonomisia ryhmiä. Lavikan mukaan homologinen suhde näiden muuten vastakkaisten rationaliteettien välillä luo olosuhteet, joissa naiset tuntevat sitoutumista ryhmätyön tavoitteisiin enemmän kuin muodollisesti vaaditaan palkkatyössä.

Naisten vastuu laajenee rajalle, jossa he ylikuormittavat itseään. Johtamisstrategia nojautuu implisiittisesti tähän sitoumukseen tuotannon päivittäisessä hoidossa, vaikka siihen ei liitykään eksplisiittistä tunnustamista palkan ja aineettomien palkintojen muodossa.

Tayloristisen perinnön ja joustavuusvaatimusten samanaikaisuus muodostavat jännitteisen yhteyden oppimiselle. Käytännöt ja niihin liittyvät normit, samoin kuin käsitykset organisaation rakenteesta ja päämääristä ja erilaisten ryhmien ase- masta organisaatiossa kehkeytyvät tulkinnallisessa prosessissa sosiaalisissa verkostoissa. Argyris'n ja Schön'n (1978) mukaan käyttöteoria on suhteellisen vakaa elementti niiden tulkintojen ja selitysten virrassa, jotka koskevat organisaation identiteettiä ja jatkuvuutta. Käyttöteoria sitoo yhteen normit, strategiat, oletuksen ja toiminnan yksityiskohtaiset säännöt. Sisäiset ja ulkoiset tekijät synnyttävät paineita muuttaa käyttöteoriaa. Tekstiili- ja vaatetusteollisuudessa kummankinlaisia paineita on läsnä johtuen pyörteisestä liiketoimintaympäristöstä.

Tiukat toimitusajat yhdistettynä äkkinäisiin muutoksiin vaativat toisenlaista työn organisoinnin tapaa kuin tayloristinen malli tarjoaa. Pienen yrityksen tapaus tuo esille esimerkin, jossa perinteinen tuotantolinja on säilyttänyt perusmuotonsa, mutta sitä oli mukautettu joustavuusvaatimusten suuntaan. Tuotantopäällikön rooli ongelmien ratkaisijana oli olennainen piirre ratkaisua vastata joustavuusvaatimuksiin, mutta myös ompelijoiden monitaitoisuus palveli samaa tarkoitusta. Ryhmätyöorganisaatiot olivat siirtäneet oppimiskysymyksen ryhmän autonomian huomaan luottaen naisten erityislaatuiseen vastuuseen ratkaista oppimishaasteet paikan päällä. Kuitenkin autonomialla oli rajansa. Hierarkiat ja funktionaalinen työnjako jatkoivat elämäänsä tehtaissa, eikä ollut harvinaista, että ryhmät kohtasivat ongelmia, joita ei voinut tosiasiallisesti ratkaista ryhmien sisäisessä maailmassa.

Tuotannon vanhojen tapojen ja mallien syrjään siirtäminen ei ole kivuton muutos ja se aiheuttaa jännitteitä suhteessa käyttöteoriaan. Taylorismiin ja joustavaan strategiaan pohjaavat toimintaodotukset ovat ristiriidassa keskenään. Selviäminen tuotantoon kohdistuvista tiukoista vaatimuksista tekee välttämättömäksi kommunikatiivisen oppimisen ja kommunikatiivisen oppimisen haasteita tulee myös tulevaisuusperspektiivien luomisesta toiminnoille. Tilanteeseen sisältyy paljon epävarmuutta ja hämmennystä. Tehtaissa ei ollut foorumeita sen paremmin ryhmissä kuin muuallakaan jännitteiden käsittelemiseksi. Kommunikatiivinen oppiminen tarvitsee foorumeita, joilla on todellinen mahdollisuus ja valtuutus tarttua ongelmiin. 
Tutkimusryhmän järjestämät keskustelutilaisuudet tarjosivat henkilöstölle mahdollisuuden tulkintakehysten pohdintaan. Tilaisuudet olivat lyhyitä, ohikiitäviä hetkiä, joiden aikana henkilöstö kykeni tuokioksi etäännyttämään itsensä päivittäisistä rutiineista. Pääasiallisesti kuitenkin perusta tilanteiden ymmärtämiselle on rakennettava normaalin työn kulussa, keskellä arkea.

\section{Lähteet}

ACKER, J. (1992): Gendering organizational theory, Teoksessa Mills, A.J. \& Tancred, P. (eds.) Gendering organizational analysis, Sage Publications, Newbury Park, Calif., ss. 248-260.

ACKER, J. (1994) The gender regime of Swedish banks, Scandinavian Journal of Management 19 (2), 117 130 .

ARGYRIS, C. and Schön, D.A. (1978) Organizational learning: A theory of action perspective, Addison-Wesley, Massachusetts.

ATKINSON, J. (1984) Manpower strategies for flexible organizations, Personnel Management 16 (8), 2831 .

BANKE, P. and Binder, T. (1992) Will new technology help Taylorism to overcome the present crisis? Results from a study on design and use of new technology in the clothing industry. In Kasvio A (ed) pp. 215-230.

BURAWOY (1985) The politics of production: Factory regimes under capitalism and socialism, Verso, London.

HARTSOCK, N. (1983): The feminist standpoint: developing the ground for a specifically feminist historical materialism. Teoksessa Discovering reality. Ed S. Harding, M. Hintikka. Reidel Publishing Company, Dordrecht, ss. 283-310.

HEISKANEN, T. (1998): Vuoropuheluun pohjaavan oppimisen haasteet. Teoksessa Heiskanen ym. (1998), ss. 167-182.

HEISKANEN, T., Hyväri, S., Kinnunen, M., Kivimäki, R., Korvajärvi, P., Lehto, A-M., Martikainen, R., Räsänen, L., Salmi M., Varsa, H., Vehviläinen, M. (1990): Työelämän sukupuolistuneet käytännöt. Tutkimussuunnitelma. Tampereen yliopisto, Yhteiskuntatieteiden tutkimuslaitos, Työelämän tutkimuskeskus, Työraportteja 20/1990.

HEISKANEN, T.,Lavikka, R., Piispa, L., Tuuli, P. (1995): Puhe on muutoksesta. Tutkimus yhteistyöstä ja muutoksen hallinnasta pukinetehtaissa. Tampereen yliopisto, Yhteiskuntatieteiden tutkimuslaitos, Työelämän tutkimuskeskus, Työraportteja 50/ 1995.

HEISKANEN, T., Lavikka, R., Piispa, L. and Tuuli, P. (1998) Joustamisen monet muodot. Pukineteollisuus etsimässä tietä huomiseen. Tampereen yliopisto, Yhteiskuntatieteiden tutkimuslaitos, Työelämän tutkimuskeskus, Sarja T-julkaisuja (17).

HOLLI, A. (1995): Tasa-arvosta ja Troijan hevosista. Feministinen käsitekritiikki ja suomalaisen tasa- arvopolitiikan käytännöt. Naistutkimus - Kvinnoforskning 8/1995, 14-32

KASVIO, A. (ed) Industry without blue-collar workers - Perspectives of European clothing industry in the 1990 's. Tampereen yliopisto, Yhteiskuntatieteiden tutkimuslaitos, Työelämän tutkimuskeskus, Työraportteja 36/1992.

KINNUNEN, M. \& Korvajärvi, P. (1996) : Työelämän sukupuolistavat käytännöt. Vastapaino, Jyväskylä.

KORVAJÄRVI, P. \& Lehto, A-M. (2000): Tietointensiivinen työ ja sukupuoli. Työ ja ihminen $2 / 2000$, 206-215.

LAVE, Jean (1993): Situating learning in communities of practice. Teoksessa Resnick, Lauren, Levine, John \& Teasley Stephanie (eds.) Perspectives on socially shared cognition, ss. 63-82, American Psychological Association, Washington DC

LAVE, Jean (1996) : The practice of learning. Teoksessa Chaiklin, Seth \& Lave, Jean (eds.) Understanding practice. Perspectives on activity and context, ss.3-32, Cambridge University Press, Cambridge

LAVIKKA, R. (1997) Big sisters. Spacing women workers in the clothing industry. University of Tampere, Research Institute for Social Sciences, Work Research Centre, Publication Series T (16).

MEZIROV, J. (1985) A critical theory of self-directed learning, New directions for continuing education, no $25,17-30$.

MEZIROV, J. et.al (1995) Uudistava oppiminen. Kriittinen reflektio aikuiskoulutuksessa. Helsingin yliopiston Lahden tutkimus- ja koulutuskeskus, Oppimateriaaleja 23, Helsinki.

PIISPA, L. (1998) Taylorismi ja joustavuus työn organisoinnin periaatteena - yhteistyön puitteet, Teoksessa Heiskanen ym, pp. 87-111.

PIISPA, L. Kontrollista suostumukseen. Julkaisematon käsikirjoitus, ei vuosilukua.

PIORE, M.J. and Sabel, C.F. (1984) The second industrial divide. Possibilities for prosperity, Basic Books, New York.

RANTALAIHO, L. and Heiskanen, T. (eds.) (1997) Gendered practices in working life, MacMillan Press Ltd.

RANTALAIHO, L, Heiskanen, T., Korvajärvi, P., Vehviläinen, M. (1997): Studying gendered practices. Teoksessa Rantalaiho, L, \& Heiskanen T. (eds), ss. 3-15.

TUULI, P. (2001): Psykologinen sopimus - näkökulma asustetehtaan työntekijöiden ja työnantajien väliseen suhteeseen. Tampereen yliopisto, pro-gradu tutkielma.

WEICK, K.E. (1995) Sensemaking in organizations, Sage, US.

WENGER, E.C \& Snyder, W.M (2000) Communities of practice: The organizational frontier. Harvard Business Review Jan-Febr., 139-145.

WINTERTON, J. (1992) The transformation of work? Work organization in the UK clothing industry. In Kasvio A (ed) pp. 273-297

Artikkeli saapui toimitukseen 10.9.2001. Se hyväksyttiin julkaistavaksi toimituskunnan kokouksessa 8.10.2001. 